\title{
Development of Financial Market and Economic Growth: Review of Hong Kong, China, Japan, The United States and The United Kingdom
}

\author{
Anson Wong (Corresponding author) \\ School of Accounting and Finance \\ The Hong Kong Polytechnic University \\ Tel: 852-2766-7866Ｅ-mail: afanson@inet.polyu.edu.hk
}

\author{
Xianbo Zhou \\ Department of Economics \\ Lingnan College, SUN YAT-SEN University, China \\ E-mail: zhouxb@mail.sysu.edu.cn
}

Received: July 20, 2010

Accepted: January 13, 2011

doi:10.5539/ijef.v3n2p111

\begin{abstract}
The empirical evidence suggests that the development of stock markets in China, USA, United Kingdom, Japan and Hong Kong have independently a strongly positive correlation with their economic growth. The result brings out an important theory to support for the proposition that the stock market development is one of the key drivers of economic growth in developed and developing countries, whatever the modes of their financial systems, stage of their economic development and types of economic system.
\end{abstract}

Keywords: Development of Stock Market, Economic Growth, China, Japan, United Kingdom, USA, Hong Kong

\section{Introduction}

Numerous studies have proposed that the development of stock market is able to improve growth performance through its positive effects on capital flows, diversification of investment risk and pooling funding for the long-term industrial projects and provision of adequate liquidity. Development of financial market drives financial innovation, greater resource allocation, efficiency, and technological advancement. Gregorio and Guidotti (1995), King and Levine (1993) have found a strong positive correlation between stock market development and economic growth.

Does stock market development have any significant impact on gross output growth in developing countries like China? How about the impacts on the developed economies e.g. USA, United Kingdom, Japan and Hong Kong? This question involves an examination of the empirical relationship between these exogenous variables (stock market development) and gross output growth.

Goldsmith (1969); Mckinnon (1973) and Shaw (1973) initially hypothesize that financial liberalization and stock market development would promote economic growth through their impacts on the growth rate of savings, investment, and thus economic growth. This is also called Mckinnon-Shaw model. Burkett (1987); Buffie (1983); Taylor (1980) argue that the stock market development may not lead to increased growth rates of output. Espinnosa and Hunter (1994) assert that a fully liberalized financial sector may not be possible or desirable in a developing economy because the stock market fluctuation would incite greater increases in financial suppression than GDP growth.

The importance of the study is to answer these issues by making a further empirical investigation. The paper is going to provide further empirical evidence on the issue, using cross-country panel data and focusing on the effects of stock market development on economic growth.

The rest of the paper is organized as follows: Section II provides a brief review of the relevant literature. Section III presents the methodology including the data used for the analysis. Empirical results are presented and discussed in Section IV. Section V concludes the paper.

\section{Literature review}

Greenwood and Jovanovic (1990) and Khan (2000) show how a well-developed financial sector can progress economic growth by pooling savings. It is because a well-functioning stock market provides funding for long-term industrial projects. Montiel (1995) indicates that the stock market not only can gather long-term funds needed for such projects but also enable the stock market to fund lumpy and risky but profitable long-term industrial projects. 
Becsi and Wang (1997) also point out that a well-developed stock market can promote efficient allocation of the accumulated savings into profitable long-term investments.

Besides, the ability to pledge adequate liquidity is another function of a well-functioning stock market. Bencivenga, et al. (1996), Demirguc-Kunt and Levine (1996) and Levine (1991) show that a highly liquid stock market makes it possible for portfolio investors to acquire financial assets and this enables industrial firms to have access to long-term funds. Levine (1991) highlights that the well-developed stock market can reduce investment risk by offering opportunities for portfolio diversification.

Also, Arestis et al (2001) found that there was not any key relationship between stock market development and economic growth after controlling for the effects of the banking system and stock market volatility. The results supported the view that both banks and stock markets would be able to promote economic growth but the effects of the former were more powerful. Levine (2002) indicated that overall stock market development was robustly linked with economic growth although there was no evidence for either the bank-based or the market-based financial systems.

The main objective of this study is to estimate the impact of stock market development on economic output growth in the market leaders and key players like the United States, the United Kingdom, Japan, China and Hong Kong; and to ascertain whether the stock market development is an important predictor of economic growth in these countries.

\subsection{Background of the Five Economies}

This paper incorporates these economies with very different stages of stock market development, different financial systems and diverse economic growth in order to prove that the development of stock markets is essential to their economic growth.

\subsubsection{Different Stages of Stock Market Development}

The stock markets in Hong Kong, China, Japan, the United Kingdom and the United States have experienced a period of rapid growth over the last few decades. Among these five economies but except China, they are mature and well-built stock markets. The history of the Hong Kong Stock Exchange began formally in the late 19th century and it has been rapidly developed since 1980s. Total market capitalization of listed companies in Hong Kong Stock Exchange significantly increased from US\$74 billion in 1988 to US\$1,162 billion in 2008. The Tokyo Stock Exchange was established on May 15, 1878. In 1943, the exchange was combined with ten other stock exchanges in major Japanese cities to form a single Japanese Stock Exchange. Nowadays, it remains the second largest stock exchange in the world by total market capitalization of listed companies at USD 4,534 billion in 2008.

The New York Stock Exchange can be traced to May 17, 1792. It is the world's largest stock exchange by market capitalization of its listed companies at US\$11,737 billion at the end of 2008. The United Kingdom, whose London Stock Exchange is one of the world's oldest stock exchanges, can trace its history back more than 300 years. The Exchange quickly grew to become the City's most important financial institution, with many overseas listings as well as British companies. As at 2008 December, total market capitalization of its listed companies was valued at USD 1,851 billion.

During the 1980s, China's securities market evolved in line with the country's economic reform. On 26 November 1990, Shanghai Stock Exchange was established again and began operation. It has been grown rapidly since the 2000s. During the period from 1991 to 2007, the market capitalization soared from USD 2 billion to USD 6,226 billion. Trading activities in Shanghai also surged rapidly. Appendix Tow also presents the growth of market capitalization of these five stock markets.

\subsubsection{Different Financial Systems}

Indeed, these five economies have different financial systems. China and Japan are bank-based financial system and that the United States, the United Kingdom and Hong Kong are market-based. It is believed that their different financial structures do matter much since the five countries have very different long-run growth rates. The bank-based system is assumed to be better at mobilizing savings, identifying good investments, and exerting sound corporate control, and managing risk. Banks can mitigate this problem as they form long-run relationships with firms and do not reveal information immediately in public markets. However, the bank-based system is also good at enhancing risk management, information disclosure, corporate governance, and capital allocation (Levine and Zervos, 1998). Markets will reduce the inherent problems associated with banks and enhance economic growth.

\subsubsection{Different Growth of Economies}

Among these five economies, they are experienced different economic development stages. China is a rapid growing country. The United States and the United Kingdom are mature economies and are playing market leaders in the world economy. Japan and Hong Kong are small but well-built economies. All these five economies accounts for almost all of total economic activities of the world. According to the World Bank statistics, the United States 
recorded 3 per cent expansion on average in the past decade and Hong Kong also experienced a growth rate of $4 \%$ in the 2000s, while The United Kingdom annually increased by $2 \%$ in the past years. However, Japan lagged behind, expanding by $1 \%$ over the decade. The Chinese economy has rapidly grown a whopping $10 \%$ since 1991 . Table 3 shows the economic growth rate of these economies from 1990s to 2000s.

\section{Methodology}

To achieve this objective, a modified version of the stock market and economic growth model formulated independently by Levine and Zervos (1996) and Demirguc-Kunt and Levine (1996) is specified and estimated over the period 1988 - 2008. The yearly data is used in the study and sourced from World Bank Development Indicator Online Database, which provide the detail information about the GDP growth rate and stock market capitalization for these five economies. Using the stock market capitalization is used as a proxy to measure the stock market development because it provides an indication of the market size which appears to be a better indicator of market development. The effect of the market capitalization on growth is estimated by specifying panel data parametric models:

$$
\log \left(G D P_{i t}\right)=c_{0}+c_{1} \log \left(M C_{i t}\right)+u_{i}+e_{i t} \text {, }
$$

where GDP is the real GDP per capita; MC is the market capitalization; $e_{i t}$ is the stochastic term satisfying $E\left[e_{i t}\right]=0$ and $E\left[e_{i t}^{2}\right]=\sigma_{e}^{2}$. The terms $u_{i}$ is the economy specific effects if they are fixed unknown parameters; they are random effects if they are random variables with $E\left[u_{i}\right]=0$ and $E\left[u_{i}\right]=\sigma_{u}^{2}$. In the later case, it is also assumed that $E\left[u_{i} u_{j}\right]=0$ for $i \neq j$ and $u_{i}$ and $e_{i t}$ are uncorrelated for all $i$ and $t$. If $u_{i}$ is assumed to be zero, the model is the constant intercept model. Here, a general form of panel data model with fixed or random effects is used in order to test the model specification.

\subsection{Empirical results}

Empirical studies using data for the period from 1988 to 2008 can be conducted to see how activities in the stock markets of the five economies affect their macro-economies. The estimation and test results of the panel data model with fixed effects and random effects are presented in Table 1. Wald F-test is used to test the null hypothesis of no fixed effects. Breusch-Pagan LM test is used to test the null of no correlation between $u_{i}+e_{i t}$ and $u_{i}+e_{i s}$ $(t \neq s)$. The Hausman's specification test is used to test the null of no difference between fixed effects and random effects. Specifically, the results in Table 1 from Wald F-test reject the homogeneity of the intercept, and hence the coefficient estimate of the constant intercept models is biased, which fails to take into account the heterogeneity of countries in our sample. The Breusch-Pagan Test for Random Effects shows that the random effects models are chosen. The Hausman's specification tests reject the null hypothesis of no systematic difference in the two coefficients, which also imply the random effects specification. Therefore, the fixed effects model is appropriate for our sample.

The estimation results of the random effects model (the last column in Table 1) show that the market capitalization has significantly positive effects on GDP. The elasticity of the market capitalization on GDP is 0.23241 , which implies that $1 \%$ increase of the market capitalization will lead to $0.23 \%$ increase of the real GDP.

Table 2 lists the fixed and random effects of the 5 economies. The random effects are very close to the fixed effects. This also justifies the result of the Hausman specification test: there is no significant difference between the fixed effects model and the random effects model.

\section{Conclusion and discussion}

The question of whether stock market development is an important factor in economic growth is empirically evaluated in this study, using cross-country panel data. Using a simple model, the empirical evidence suggests that the stock market development has independently a strong positive correlation with industrial production. The result brings out an important theory to support for the proposition that the stock market development is one of the key drivers of economic growth in countries, whatever the modes of their financial systems, stage of their economic development and types of economic system.

In view of the provision over the exact role of the stock market development in economic growth, the results of the present study should not be viewed as conclusive empirical evidence, but rather as an additional inspiration for further research in this area.

\section{References}

Arestis, P., Demetriades, P. O.\& Luintel, K. B. (2001). Financial development and economic growth: the role of stock markets, Journal of Money, Credit \& Banking February 01, 16-41.

Becsi, Z. \& Wang, P (1997). Financial development and growth, Federal Reserve Bank of Atlanta Economic Review, Fourth Quarter, 46-62. 
Bencivenga, et al. (1996). Equity markets, transaction costs, and capital accumulation. an illustration, The World Bank Economic Review 10:2, 241- 265.

Burkett, P (1987). Financial 'repression' and financial 'liberalisation' in the third world: a contribution of the critique of neoclassical development theory, Review of Radical Political Economy 19:1, 1-21. doi:10.1177/048661348701900101, http://dx.doi.org/10.1177/048661348701900101

Buffie, E. F. (1984). Financial repression, the new structuralists, and stabilization policy in semi-industrialised economies, Journal of Development Economics 14, 305-322. doi:10.1016/0304-3878(84)90061-0, http://dx.doi.org/10.1016/0304-3878(84)90061-0

Demirguc-Kunt, A, and Levine, R. (1996). Stock market development and financial intermediaries: stylised facts, The World Bank Economic Review 10: 2, 291-321.

Espinosa, M., \& Hunter, W.C. (1994). Financial repression and economic development, Federal Reserve Bank of Atlanta Economic Review 79:5, September/October, 1-11.

Goldsmith, R. W. (1969) Financial Structure and Development. New Haven, CT: Yale University Press.

Gregorio, D. J. \& Guidotti, P.E. (1995). Financial development and economic growth, World Development 23:3, 433-448. doi:10.1016/0305-750X(94)00132-I, http://dx.doi.org/10.1016/0305-750X(94)00132-I .

Greenwood, J, \& Jovanovic, H. (1990). Financial development, growth and the distribution of income, Journal of Political Economy 98, 1076-1107. doi:10.1086/261720, http://dx.doi.org/10.1086/261720

Khan, A. (2000). The finance and growth nexus, Federal Reserve Bank of Philadelphia Business Review, January/February, 3- 14.

King, R. G., and Levine, R. (1993). Finance entrepreneurship, and growth: theory and evidence, Journal of Monetary Economics 32:3, $513 \quad-\quad$ 542. $\quad$ doi:10.1016/0304-3932(93)90028-E, http://dx.doi.org/10.1016/0304-3932(93)90028-E

Levine, R. and Zervos, S. (1998). Capital control liberalization and stock market development, World Development 26, 1169-1183. doi:10.1016/S0305-750X(98)00046-1, http://dx.doi.org/10.1016/S0305-750X(98)00046-1

Levine,R. (2002). Bank-based or market-based financial systems: which is better?, Journal of Financial Intermediation, 11:4, 398-428. doi:10.1006/jfin.2002.0341, http://dx.doi.org/10.1006/jfin.2002.0341

Levine, R. (1991). Stock market, growth, and tax policy, Journal of Finance 46, September. 1445-65. doi:10.2307/2328866, http://dx.doi.org/10.2307/2328866

Levine, R. \& Zervos, S. (1996). Stock market development and long-run growth. The World Bank Economic Review 10: 2, 323-329.

Mckinnon, R. I. (1973). Money and Capital in Economic Development. Washington, D. C.: Brookings Institution.

Taylor, L. (1980) IS/LM in the tropics: Diagrammatics of the new structuralist macro critique. In C. William and S. Weintraub (eds.) Economic Stabilization in Developing Countries. Washington, D. C.: Brooking Institution.

*Note: The co-author'sfunding project in the paper as follows; Zhou's research was supported by the National Natural Science Foundation of China (Grant: 70971143)

Table 1. Estimation and test results of panel data models (constants not reported)

\begin{tabular}{|l|l|l|l|}
\hline Model & Constant intercept model & $\begin{array}{l}\text { Fixed effects } \\
\text { model }\end{array}$ & $\begin{array}{l}\text { Random effects } \\
\text { model }\end{array}$ \\
\hline $\begin{array}{l}\text { Coefficient estimate } \\
\text { (t-ratio) }\end{array}$ & 0.82183 & 0.2361 & 0.23241 \\
$(15.262)$ & $(12.687)$ \\
\hline Wald F-Test for Fixed Effects & $(17.325)$ & $\mathrm{F}(4,100)=598.12$ \\
\hline Breusch-Pagan Test for Random Effects & Chi-Sq $(1)=301.52$ \\
\hline Hausman Test: Fixed or Random Effects & Chi-Sq $(1)=0.5823$ \\
\hline
\end{tabular}

Table 2. Fixed and random effects of the five countries

\begin{tabular}{|l|l|l|l|l|}
\hline Country & Fixed effects & Standard errors & Random effects & Standard errors \\
\hline Hong Kong & 0.3469 & 0.2004 & 0.3104 & 0.2312 \\
\hline China & 0.2986 & 0.1952 & 0.3228 & 0.2132 \\
\hline Japan & 0.5347 & 0.2133 & 0.4219 & 0.1293 \\
\hline United Kingdom & 0.1724 & 0.2153 & 0.0801 & 0.0141 \\
\hline USA & 0.6709 & 0.2943 & 0.6152 & 0.2208 \\
\hline
\end{tabular}


Table 3. GDP growth rate among five economies (\%)

\begin{tabular}{|l|l|l|l|l|l|}
\hline Year & China & Hong Kong SAR, China & Japan & United States & United Kingdom \\
\hline 1988 & 11 & 8 & 7 & 4 & 5 \\
\hline 1989 & 4 & 2 & 5 & 4 & 2 \\
\hline 1990 & 4 & 4 & 5 & 2 & 1 \\
\hline 1991 & 9 & 6 & 3 & -0 & -1 \\
\hline 1992 & 14 & 6 & 1 & 3 & 0 \\
\hline 1993 & 14 & 6 & 0 & 3 & 2 \\
\hline 1994 & 13 & 6 & 1 & 4 & 4 \\
\hline 1995 & 11 & 2 & 2 & 3 & 3 \\
\hline 1996 & 10 & 4 & 3 & 4 & 3 \\
\hline 1997 & 9 & 5 & 2 & 5 & 3 \\
\hline 1998 & 8 & -6 & -2 & 4 & 4 \\
\hline 1999 & 8 & 3 & -0 & 4 & 3 \\
\hline 2000 & 8 & 8 & 3 & 4 & 4 \\
\hline 2001 & 8 & 0 & 0 & 1 & 2 \\
\hline 2002 & 9 & 2 & 0 & 2 & 2 \\
\hline 2003 & 10 & 3 & 1 & 3 & 3 \\
\hline 2004 & 10 & 8 & 3 & 4 & 3 \\
\hline 2005 & 10 & 7 & 2 & 3 & 2 \\
\hline 2006 & 12 & 7 & 2 & 3 & 3 \\
\hline 2007 & 13 & 6 & 2 & 2 & 3 \\
\hline 2008 & 9 & 2 & -1 & 0 & 1 \\
\hline
\end{tabular}

Source: World Bank Development Indicator Online Database

Table 4. Market capitalization (USD million)

\begin{tabular}{|l|l|l|l|l|l|}
\hline Year & China & Hong Kong SAR, China & Japan & United States & United Kingdom \\
\hline 1988 & N.A. & 74,400 & $3,910,000$ & $2,790,000$ & 771,000 \\
\hline 1989 & N.A. & 77,500 & $4,390,000$ & $3,510,000$ & 827,000 \\
\hline 1990 & N.A. & 83,400 & $2,920,000$ & $3,060,000$ & 849,000 \\
\hline 1991 & 2,030 & 122,000 & $3,130,000$ & $4,090,000$ & 988,000 \\
\hline 1992 & 18,300 & 172,000 & $2,400,000$ & $4,490,000$ & 927,000 \\
\hline 1993 & 40,600 & 385,247 & $2,999,756$ & $5,136,199$ & $1,151,646$ \\
\hline 1994 & 43,500 & 269,508 & $3,719,914$ & $5,067,016$ & $1,210,245$ \\
\hline 1995 & 42,055 & 303,705 & $3,667,292$ & $6,857,622$ & $1,407,737$ \\
\hline 1996 & 113,755 & 449,381 & $3,088,850$ & $8,484,433$ & $1,740,246$ \\
\hline 1997 & 206,366 & 413,323 & $2,216,699$ & $11,308,779$ & $1,996,225$ \\
\hline 1998 & 231,322 & 343,394 & $2,495,757$ & $13,451,352$ & $2,374,273$ \\
\hline 1999 & 330,703 & 609,090 & $4,546,937$ & $16,635,114$ & $2,933,280$ \\
\hline 2000 & 580,991 & 623,398 & $3,157,222$ & $15,104,037$ & $2,576,992$ \\
\hline 2001 & 523,952 & 506,073 & $2,251,814$ & $13,854,616$ & $2,164,716$ \\
\hline 2002 & 463,080 & 463,085 & $2,126,075$ & $11,098,102$ & $1,864,262$ \\
\hline 2003 & 681,204 & 551,237 & $3,040,665$ & $14,266,266$ & $2,460,064$ \\
\hline 2004 & 639,765 & 665,248 & $3,678,262$ & $16,323,726$ & $2,815,928$ \\
\hline 2005 & 780,763 & 693,486 & $4,736,513$ & $16,970,865$ & $3,058,182$ \\
\hline 2006 & $2,426,326$ & 895,249 & $4,726,269$ & $19,425,855$ & $3,794,310$ \\
\hline 2007 & $6,226,305$ & $1,162,566$ & $4,453,475$ & $19,947,284$ & $3,858,505$ \\
\hline 2008 & $2,793,613$ & 468,595 & $3,220,485$ & $11,737,646$ & $1,851,954$ \\
\hline
\end{tabular}

Source: World Bank Development Indicator Online Database 